\title{
Effects of Early Post-Mortem Rate of pH fall and aging on Tenderness and Water Holding Capacity of Meat from Cull Dairy Holstein-Friesian Cows
}

\author{
Carlos Santos ${ }^{1}$, Carlos Moniz 2 , Cristina Roseiro ${ }^{1}$, Marina Tavares ${ }^{2}$, Vera Medeiros ${ }^{2}$, Isabel Afonso ${ }^{2}$, Manuel A. \\ Dias $^{3}$ \& Duarte J. B. da Ponte ${ }^{4}$ \\ ${ }^{1}$ Instituto Nacional de Investigação Agrária e Veterinária, I.P., Unidade Estratégica de Investigação e Serviços de \\ Tecnologia e Segurança Alimentar, Campus do IAPMEI, Edifício S, Estrada do Paço do Lumiar, 22, 1649-038 \\ Lisboa. Portugal \\ ${ }^{2}$ Instituto de Inovação Tecnológica dos Açores, Estrada de S. Gonçalo, 9504-540, Ponta Delgada, Açores, \\ Portugal \\ ${ }^{3}$ Alicontrol - Tecnologia e Controlo de Alimentos, Lda., Rua Fernando Vaz, Lote 26-B, 1750-108 Lisboa, Portugal \\ ${ }^{4}$ Universidade dos Açores, Departamento de Ciências Tecnológicas e Desenvolvimento, Rua Mãe Deus, 9500-321 \\ Ponta Delgada, Açores, Portugal \\ Correspondence: Carlos Santos, Instituto Nacional de Investigação Agrária e Veterinária, I.P. Unidade Estratégica \\ de Investigação e Serviços de Tecnologia e Segurança Alimentar. Campus do IAPMEI, Edifício S, Estrada do \\ Paço do Lumiar, 22, 1649-038 Lisboa. Portugal. Tel: 351-217-127-108. E-mail: carlos.santos@iniav.pt
}

Received: November 17, 2015 Accepted: December 1, 2015 Online Published: March 8, 2016

doi:10.5539/jfr.v5n2p1

URL: http://dx.doi.org/10.5539/jfr.v5n2p1

\begin{abstract}
Fast or slow muscle $\mathrm{pH}$ fall may give unacceptable purge losses or tough meat, depending much on concomitant evolution of muscle temperature early post-mortem, costing millions of euros to the meat industry. Tenderness and purge losses of Longissimus thoracis/lumborum (LTL) and Gluteus medius $(\mathrm{Gm})$ sampled from cull dairy cows differing in production status (10 lactating vs. 22 dried off) and aging time, were evaluated regarding different rates of $\mathrm{pH}_{2}$ fall. Shear force related to $\mathrm{pH}_{2}$ was dependent on muscle and aging time. The intermediate glycolysis led to lower shear force in $L T L$, while the faster produced best quality in $G m$. Purge was influenced by $\mathrm{pH}_{2}(\mathrm{P}=0.0077)$, aging $(\mathrm{P}<0.0001)$ and muscle* $\mathrm{pH}_{2}$ interaction $(\mathrm{P}<0.0001)$. Aging affected thawing $(\mathrm{P}<0.0001)$, grilling $(\mathrm{P}=0.0004)$ and overall losses $(\mathrm{P}<0.0001)$. Under the ruled chilling regime, the fast $\mathrm{pH}$ fall in $G m$ and the slow $\mathrm{pH}$ fall in $L T L$ approached out of the ideal $\mathrm{pH} 6 /$ temperature limits, being compatible with heat and cold shortening, respectively.
\end{abstract}

Keywords: cull dairy cows, aging, $\mathrm{pH}$ fall rate, tenderness, purge loss, thawing loss

\section{Introduction}

Meeting consumer requirements is a major concern for meat producers and retailers. Retaining moisture and a high tenderness degree are considered important meat traits for consumer acceptability (Lonergan \& Lonergan, 2005; Miller, Carr, Ramsey, Crockett, \& Hoover, 2001). Purge losses reach as much as $1-3 \%$ in fresh retail cuts developing a normal quality pattern (Offer and Knight, 1988) or rise up to about $10-15 \%$ in abnormal muscle quality condition, such as the extremely PSE pork products (Roseiro et al., 1994; Melody et al., 2004). The loss of water from cell compartments is associated to different mechanisms, which may occur at distinct storage phases (Lonergan \& Lonergan, 2005). With the polarity inversion occurring in cell membranes at the early stages of the apoptosis process taking place in muscles after bleeding and $\mathrm{O}_{2}$ depletion (Ouali et al., 2006), the acidic components formed by glycolysis are replaced by others of basic nature, promoting partial neutralization and/or slowing down acidification, giving rise to transient "plateaus" in the pH fall dynamics (Herrera-Mendez, Becila, Boudjellal \& Ouali, 2006). Such discontinuity in $\mathrm{pH}$ fall can not be addressed to any transient reduction of glycolytic enzymes activities (phosphocreatine kinase and others) but to modifications of either the buffering capacity and/or charge distribution within the muscle cell (replacement of acidic phosphatidylserine by basic components, such as phosphatidylcholine and phosphatidylethanolamine) (Ouali et al., 2006). Partial denaturation of myosin head at low $\mathrm{pH}$, namely when the muscle temperature is high, is also thought to be a 
mechanism involved in the shrinkage of the myofibrillar spacing and the subsequent purging development (Offer $\&$ Trinick, 1983; Offer, 1991). In the other hand, modifications occurring in costameres, as the ones affecting the lateral shrinkage of the myofibrils (Honikel, Kim, Hamm \& Roncales, 1986; Kristensen \& Purslow, 2001; Bertram, Purslow \& Andersen, 2002), also contribute to sarcomeres shortening and cell volume shrinkage. Both events, occurring under a general apoptosis process (Ouali et al., 2006), would create channels between cells and cell bundles, facilitating the purging out from meat (Offer \& Knight, 1988; Schafer, Rosenvold, Purslow, Andersen, \& Henckel, 2002). Thus, different post-mortem $\mathrm{pH}$ decline rates would influence the meat quality standards (Kauffman \& Marsh, 1987; Marsh, 1993), since it influences the proteinaceous linkages formed post-mortem (Dransfield, 1992; Geesink et al., 1995; Sentandreu, Coulis, \& Ouali, 2002) as well as the proteolytic degradation of myofibrils (Salm et al., 1983) and collagen (Judge, Reeves, \& Aberle, 1981). The conjunction of high muscle temperature and fast $\mathrm{pH}$ decline can also result in protein/enzymes denaturarion/autolysis, thus minimizing tenderness improvement as the post-mortem storage progresses (Dransfield, Etherington, \& Taylor, 1992; Rees, Trout, \& Warner, 2003).

Cull dairy cows represent near $50 \%$ of the overall cattle population slaughtered at S. Miguel (Azores), with a carcass weight amounting to 9,600 tones in 2013. Despite poor carcasses meat yield (70\% scored as P; $30 \%$ as $\mathrm{O}$ ), an important amount of lean meat is still produced from hindquarter noble cuts. In view of the multiple subjacent reasons for culling, dairy cows are considerably heterogeneous in age and production status at slaughter, making expectable different final meat quality patterns.

The present study was undertaken to evaluate the relationship between muscle early post-mortem rate of $\mathrm{pH}$ fall (up to 6 hours) and meat purge losses and Warner-Bratzler (WB) shear force of mature dairy culled cows, after aging for 2, 7, 14, 28 and 42 days. Thawing and grilling weight losses after aging were also examined. The validity of those quality trait values against the ideal $\mathrm{pH} /$ temperature window expectations was also evaluated.

\section{Materials and Methods}

\subsection{Animals and Carcasses Handling}

Thirty two culled dairy cows (lactating- 10 cows; dried-off - 22 cows) were used for the present study. They were reared at different farms and fed under a regime based on natural pasture or green silage and concentrate until drying (diet restriction to straw concomitantly with some water deprivation or, simultaneously by mating, personal communication). Cows were slaughtered conventionally at a commercial abattoir, in average 2 cows/day, depending on their availability in farms according to the variables under study (Table 1). Carcasses were electrically stimulated $(90 \mathrm{~V})$ for about 1 minute during the bleeding stage, about 5 minutes after stunning (captive bolt). After dressing, weighting and classification [conformation and fatness, according to EC Regulation $\left.\mathrm{N}^{\circ} 103 / 2006\right]$, carcass sides were cooled down in a chiller at $0{ }^{\circ} \mathrm{C}-1{ }^{\circ} \mathrm{C}$ and $3-4 \mathrm{~m} / \mathrm{s}$ ventilation rate for about 1 hour and then chilled at $2{ }^{\circ} \mathrm{C}$ and $0.5-1 \mathrm{~m} / \mathrm{s}$ ventilation rate, for the next 48 hours. At this stage, the LTL (quarters separated at the $12^{\text {th }}$ rib level) and the whole $G m$ muscles were taken from the left hindquarter and sent under refrigeration to the laboratory for analysis.

Table 1. Live culled cows characteristics and respective carcasses quality attributes used in the experimental design

\begin{tabular}{|c|c|c|c|c|c|c|}
\hline \multirow[t]{2}{*}{$\mathrm{n}$} & \multirow[t]{2}{*}{ Production status } & \multirow{2}{*}{$\begin{array}{c}\text { Age } \\
\text { (months) }\end{array}$} & \multirow{2}{*}{$\begin{array}{c}\text { Carcass weight } \\
(\mathrm{kg})\end{array}$} & \multicolumn{2}{|c|}{$\begin{array}{c}\text { Carcass yield } \\
\text { (EUROP) }\end{array}$} & \multirow{2}{*}{$\begin{array}{c}\text { Carcass fatness } \\
\qquad(1 ; 2 ; 3 ; 4)\end{array}$} \\
\hline & & & & $\mathrm{P}$ & $\mathrm{O}$ & \\
\hline 10 & Lactating & 76.3 & 273.7 & $70 \%$ & $30 \%$ & 2.2 \\
\hline 22 & Dried-off & 85.4 & 310.5 & $65 \%$ & $35 \%$ & 2.6 \\
\hline
\end{tabular}

\section{$2.2 \mathrm{pH}$ and Temperature Monitoring}

During cooling stage of carcass sides, the $\mathrm{pH}$ in LTL (between L1 and L2 vertebrae) and Gm (approximately at the central point of muscle visible area on the carcass) muscles were measured by means of a scalpel incision and then inserting a glass electrode for penetration (Ingold, lot406-M6-DKX), approximately 3-4 cm deep in the muscle, using a portable $\mathrm{pH}$ meter (Crison 507, 08328 Alella, Spain). Measurements were taken every $1 / 2$ hour for the first 6 hours post-mortem for the evaluation of glycolysis rate. When the $\mathrm{pH}$ did not change in relation to the previous value in two or more consecutive measurements, a transient step (plateau formation) was considered 
to exist. The final $\mathrm{pH}$ was measured 48 hours post-mortem and samples having a $\mathrm{pH}_{48}$ higher than 6.0 were not used in this study. Muscles were grouped according to fall rate of $\mathrm{pH}$ measured at $2 \mathrm{~h}$ post-mortem $\left(\mathrm{pH}_{2}\right)$ as follows: slow $\left(\mathrm{pH}_{2}>6.4\right)$, intermediate $\left(6.0<\mathrm{pH}_{2}<6.4\right)$ and fast $\left(\mathrm{pH}_{2}<6.0\right)$. During this period of time, muscle temperature was also continuously monitored throughout a probe connected to a Delta -T Logger (Delta $-\mathrm{T}$ devices, Burwell, Cambridge, UK).

\subsection{Purge Loss and Shear Force Evaluation}

Sub-samples of $L T L$ and $G m$ muscles randomly assigned to each aging condition (vacuum packed and held at $2^{\circ} \mathrm{C}$ for $2,7,14,28$ and 42 days) were used to evaluate related purge losses $\%=$ [fresh meat weight - (meat weight after each aging period)] x 100 / fresh meat weight. After aging, samples were dried with adsorbent paper, cut into two similar portions, vacuum packed, immediately frozen at $-30^{\circ} \mathrm{C}$ and held thereafter at $-18^{\circ} \mathrm{C} /-20^{\circ} \mathrm{C}$ until grilling. Thawing and grilling losses (\%) were calculated as follows: [aged samples weight - (thawed or grilled sample weight) $\mathrm{x} 100]$ / aged sample weight. Total meat losses $(\%)=[$ initial fresh meat weight - (aging losses + thawing losses + grilling losses)] x 100 / initial fresh meat weight.

For shear force evaluation, samples about $2.5-3.0 \mathrm{~cm}$ thick were cooked in a water bath at $85{ }^{\circ} \mathrm{C}$ until $70{ }^{\circ} \mathrm{C}$ in the critical point, cooled down in ice water for about 30 minutes and then stored under vacuum packaging in a refrigerator $\left(0-2{ }^{\circ} \mathrm{C}\right)$. Before analysis, samples were kept at room temperature $\left(15-18^{\circ} \mathrm{C}\right)$ for equilibrium. Square sectioned cores $(1 \times 1 \times 4 / 5 \mathrm{~cm})$ for Warner-Blatzer (WB) shear tests $(500 \mathrm{~kg}$ cell) were prepared parallel to the muscle fibers direction. Before analysis, they were consistently held at room temperature for about $1 / 2$ hour (equalization) and then completely cut by the shear blade (triangular slot cutting edge, of $1 \mathrm{~mm}$ of thickness), perpendicular to the fibers, at a crosshead speed of $1 \mathrm{~mm} / \mathrm{s}$ (Instron 4501 model, H3279, England). Each mean value was obtained from six to ten recordings and expressed as Newtons.

\subsection{Statistical Analysis}

To determine the effect of rate $\mathrm{pH}$ fall and aging time on variation of purge losses and shear force values, analysis of variance (ANOVA) was performed using JMP statistical software (Version 9.0.1, SAS Institute, Inc., Cary, NC, USA, 2010), following a linear mixed model. When significantly affected $(P<0.05)$, least square means were compared using the Tukey HSD post hoc test.

The relationship between $\mathrm{pH}$ and temperature was examined in order to determine the risk of cold and heat-shortening occurrence in the two muscles $(G m$ and $L T L)$ grouped according the different rates of $\mathrm{pH}_{2}$ fall studied. Second-order polynomial regression was the best model for the fitting of data.

\section{Results and Discussion}

\subsection{Variation in the Rate of Muscles $p H$ Fall}

Within the wide range of glycolytic rates found in both muscles among carcasses at 2 hours post-mortem (Table 2), no particular $\mathrm{pH}$ evolution pattern (slow, intermediate or fast $\mathrm{pH}$ fall) by age and production status of cows at slaughter was found. Since no additive effect in the glycolytic variation was objectively induced by cooling rate (same chilling regime applied) and considering the scored EUROP carcass classification (Table 1), which indicates that most of them would cool down at similar rates, the results show that the electrical stimulation response differed strongly among tested animals with normal muscle $\mathrm{pH}_{48}(\mathrm{Gm}$ - between 5.76 and 5.38; LTL between 5.92 and 5.41) (Table 2). The slope of $\mathrm{pH}$ decline between 2 and 6 hours post-mortem was more pronounced in the $G m$ muscle, namely with intermediate $\left(0.66 \mathrm{pH}\right.$ units) and slow $(0.95 \mathrm{pH}$ units $) \mathrm{pH}_{2}$ evolutions when compared to $L T L$ muscle ( 0.31 and $0.69 \mathrm{pH}$ units, respectively). Concerning the faster $\mathrm{pH}_{2}$ group, differences between muscles were not so great ( $G m-0.43 \mathrm{pH}$ units vs. $L T L-0.38 \mathrm{pH}$ units).

No evident transient $\mathrm{pH}$ stability pattern was found within the $\mathrm{pH}_{2}$ groups for each muscle type, probably due to the interference of electrical stimulation applied to carcasses. Corroborating the results reported by Ouali et al. (2006), our muscles also showed, most frequently, one transient stage (55\%), followed by those having two $(36 \%)$ and none (9\%). In terms of post-mortem timing, plateaus mostly appeared after the first 2 hours following slaughter but one $\mathrm{Gm}$ muscle exhibited a short event during the first hour post-mortem. Only one case with 2 concomitant plateaus in both muscles of the same carcass was found, with this transient frequency profile being slightly higher in $L T L$ muscle. 
Table 2. $\mathrm{pH}_{2}$ means, minimum and maximum values within each $\mathrm{pH}_{2}$ group in $G m$ and $L T L$ muscles

\begin{tabular}{|c|c|c|c|c|c|}
\hline & & \multicolumn{3}{|c|}{ Rate pH fall } & \multirow[b]{2}{*}{$\mathbf{p H}_{48}$} \\
\hline & & $\begin{array}{c}\text { Fast } \\
\mathrm{pH}_{2}<6.0\end{array}$ & $\begin{array}{c}\text { Intermediate } \\
6.0<\mathrm{pH}_{2}<6.4\end{array}$ & $\begin{array}{c}\text { Slow } \\
\mathrm{pH}_{2}>6.4\end{array}$ & \\
\hline \multirow[t]{4}{*}{$G m$} & $\mathrm{n}$ & 16 & 12 & 4 & 32 \\
\hline & mean & 5.78 & 6.12 & 6.60 & 5.60 \\
\hline & $\min$ & 5.51 & 6.00 & 6.50 & 5.38 \\
\hline & $\max$ & 5.96 & 6.38 & 6.70 & 5.76 \\
\hline \multirow[t]{4}{*}{$L T L$} & $\mathrm{n}$ & 14 & 11 & 7 & 32 \\
\hline & mean & 5.81 & 6.15 & 6.58 & 5.64 \\
\hline & $\min$ & 5.63 & 6.00 & 6.40 & 5.41 \\
\hline & $\max$ & 5.98 & 6.39 & 6.72 & 5.92 \\
\hline
\end{tabular}

$\mathrm{pH}_{2}-\mathrm{pH}$ measured $2 \mathrm{~h}$ post-mortem; $\mathrm{pH}_{48}-\mathrm{pH}$ measured $48 \mathrm{~h}$ post-mortem.

\subsection{Early Post-Mortem Muscle pH Condition and Meat Shear Force}

The tendency of meat from muscles with two $\mathrm{pH}$ transient steps to be tougher than that having only one (Ouali et al., 2006), was not confirmed in our study. The results from LTL muscle (Table 3) show the former samples type with significantly improved overall mean tenderness $(45.49 \mathrm{~N}$ vs. $58.89 \mathrm{~N})$, with such difference consistently registered up to the 14 days aging period. The tenderization process within samples with $2 \mathrm{pH}$ transient steps was apparently faster than in the other groups, reaching a mean shear force level at day 2 of aging equivalent to those obtained after 28 ( 1 transient step) and 14 days (no transient step). The evolution of meat tenderness with the extension of aging also differed among the 3 groups, varying those samples with 2 transient stages, comparatively, between more narrowed limits ( $49.83 \mathrm{~N}$ at day 2 and $41.35 \mathrm{~N}$ at day 14). The other two groups (0 and 1 transient step) behaved similarly, showing a more extended but progressive decreasing of values. It must be yet underlined that the mean shear force in samples with 1 transient step tended to stabilize around $58.8 \mathrm{~N}$ somewhere between day 7 and day 14 and those having no transient steps showed the best mean tenderness degree after 28 days of aging $(39.72 \mathrm{~N})$. This last result must be taken under reserve due to the exiguous number of tested samples (Table 3) and the enormous difference in values found between them. The shear force discrimination between samples with two and one $\mathrm{pH}$ transient steps can not be dissociated from the results obtained with 3 samples within the later group, which shear force mean values were seemingly above $100 \mathrm{~N}$ along the entire aging duration. Among such cases, only one had a $\mathrm{pH}_{2}>6.4$, which according to the data represented in Figure 1, could be cold-shortened, while the other two had intermediate $\mathrm{pH}_{2}$ evolutions, which make the cold-shortening occurrence almost unlikely (van de Ven, Pearce \& Hopkins, 2013). The exact meaning of $\mathrm{pH}$ transient steps and their expected effects in the multiple enzyme systems activity involved in meat tenderization calls for new investigations, to clarify their subjacent complex mechanisms and the key interacting factors determining their functionality.

Table 3. Shear force $(\mathrm{N})$ mean values $( \pm \mathrm{SE})$ in LTL muscle aged for 7, 14, 28 and 42 days of culled dairy cows as affected by the frequency of $\mathrm{pH}$ transient steps ocurred up to 6 hours post-mortem

\begin{tabular}{|c|c|c|c|c|c|c|}
\hline \multirow{2}{*}{$\begin{array}{c}\mathrm{pH} \\
\text { transient steps }\end{array}$} & \multicolumn{6}{|c|}{ Aging time (days) } \\
\hline & $n$ & 2 & 7 & 14 & 28 & Overall mean \\
\hline 0 & 2 & $77.52 \pm 25.15$ & $57.47 \pm 7.30$ & $51.39 \pm 3.73$ & $39.72 \pm 4.71$ & $56.52 \pm 7.25^{\mathrm{ab}}$ \\
\hline 1 & 12 & $69.88 \pm 9.66$ & $58.81 \pm 9.98$ & $58.84 \pm 6.82$ & $48.04 \pm 5.94$ & $58.89 \pm 4.16^{\mathrm{a}}$ \\
\hline 2 & 8 & $49.83 \pm 5.23$ & $46.10 \pm 5.09$ & $41.35 \pm 3.19$ & $44.67 \pm 4.27$ & $45.49 \pm 2.22^{b}$ \\
\hline \multicolumn{7}{|l|}{ Significance: } \\
\hline pH transient steps (TS) & & \multicolumn{4}{|c|}{0.016} & 0.022 \\
\hline Aging time (AT) & & \multicolumn{4}{|c|}{0.018} & \\
\hline$T S^{*} A T$ & & \multicolumn{4}{|c|}{0.314} & \\
\hline
\end{tabular}

Overall means with different superscript letters are significantly different, $\mathrm{P}<0.05$ (Tukey HSD post hoc test). 
The fitting curves for $\mathrm{pH}$ vs. temperature evolution recorded from $G m$ and $L T L$ muscles are represented in Figure 1. They express well how different the rates of decline and the relationship with the "ideal pH/temperature window" concept reported by Hopkins, Ponnampalam, van de Ven \& Warner (2014) can be. The temperature/pH 6.0 fitting curve in $L T L$ muscle for the slow group passed out $\left(8.8^{\circ} \mathrm{C}\right)$ the safe interval defined between $35{ }^{\circ} \mathrm{C}$ and $12{ }^{\circ} \mathrm{C}$. However, it is obvious that within this group some samples still crossed safely the quality window at the coldest end. Apart from very few exceptions, intermediate and fast $L T L$ samples crossed that safety interval at $17.95{ }^{\circ} \mathrm{C}$ and $30.25{ }^{\circ} \mathrm{C}$, respectively. In view of its anatomical location and predominant metabolic profile of fibres, the temperature/pH fitting curves in $\mathrm{Gm}$ muscle approached all through the ideal interval for quality. However, samples from the fast group touched it just at the hottest point (temperature/pH 6.0 $=35.0^{\circ} \mathrm{C}$ ), which means that some of them would be exposed to some degree of heat shortening.
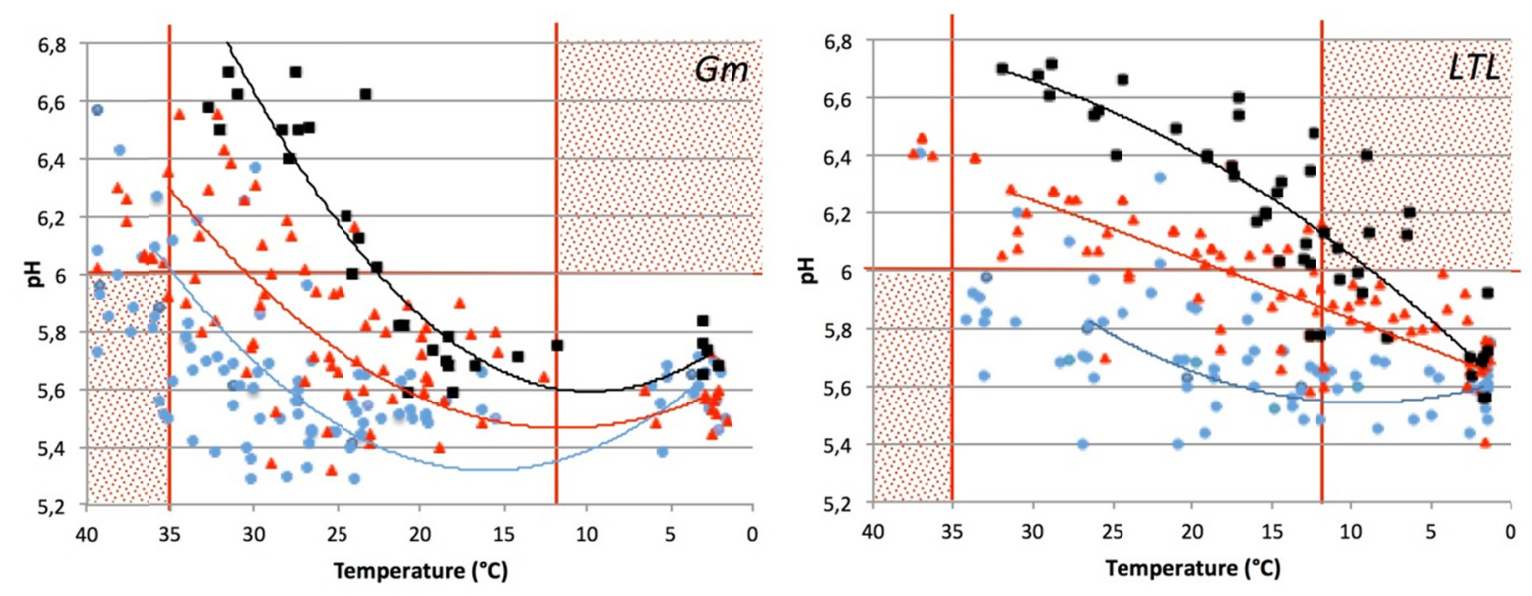

Figure 1. Fitting of $\mathrm{pH}$ and temperature relationship, according a second-order polynomial regression model for Gm and LTL muscles, grouped by the different rates of $\mathrm{pH}_{2}$ fall studied (fast $\bullet$; intermediate (10); slow $\mathbf{\square}$ ). Gluteus medius: fast $\left(\mathrm{y}=0.0019 \mathrm{x}^{2}-0.0611 \mathrm{x}+5.804, \mathrm{R}^{2}=0.797\right)$; intermediate $\left(\mathrm{y}=0.0015 \mathrm{x}^{2}-0.0346 \mathrm{x}+5.662\right.$, $\left.\mathrm{R}^{2}=0.984\right)$; slow $\left(\mathrm{y}=0.0026 \mathrm{x}^{2}-0.0504 \mathrm{x}+5.839, \mathrm{R}^{2}=0.937\right)$. Longissimus thoracis/lumborum: fast $\left(y=0.001 x^{2}-0.0179 x+5.626, R^{2}=0.856\right)$; intermediate $\left(y=0.00002 x^{2}+0.0215 x+5.621, R^{2}=0.994\right)$; slow $\left(y=-0.0006 x^{2}+0.0533 x+5.576, R^{2}=0.995\right)$

According to Devine, Wahlgren and Tornberg (1999) and Devine et al. (2002) this meat should present increased toughness, in a less extent than the cold shortened samples, and yet a lower ability to tenderize with aging. The fitting curve of temperature at $\mathrm{pH} 6.0$ for the intermediate group was $30.5^{\circ} \mathrm{C}$, but the variation in $\mathrm{pH} /$ temperature distribution among this group still brings few samples into expectable heat shortening development zone. The slow group passed through the temperature/pH 6.0 interval close to the ideal point reported by Locker \& Hagyard (1963) and Tornberg (1996), as giving the minimal toughness $\left(22.2{ }^{\circ} \mathrm{C}\right)$. The quality expectations evidenced by data in Figure 1 were almost fully confirmed by the results in Tables 4 and 5, which clearly demonstrate the accuracy in predicting the meat eating quality through this grading system.

The meat shear force in both muscles was significantly affected by aging time ( $L T L$ and $G m-P<0.001)$. The rate of $\mathrm{pH}_{2}$ fall only significantly affected the shear force in $L T L$ muscle $(P=0.038)$ in accordance with the findings reported by Marsh, Ringkob, Russell, Swartz \& Pagel (1987). These authors associated the higher values in slower samples with cold shortening effects, but they also clearly assumed that this phenomenon could not be accounted as the main cause of tenderness deterioration. In fact, despite the higher probability of cold shortened LTL within our slower $\mathrm{pH}_{2}$ group, that effect appeared to be restricted to a very short period of time and to the muscles out layer (results not shown). Regardless the mechanisms involved, a clear degradation of tenderness occurred, mainly for the shorter aging periods, about $20 \mathrm{~N}$ higher than in the other $\mathrm{pH}_{2}$ groups (Table 5). The overall difference between the worse and best shear force conditions was still higher within the LTL than in Gm $(16.18 \mathrm{~N}$ vs. $8.60 \mathrm{~N})$. Despite some recovering in tenderization dynamic in $L T L$ slow group, somewhere between day 7 and day 14 of aging, the difference between this condition and that best performing (intermediate $\mathrm{pH}_{2}$ fall rate) still remained considerable after 28 days of aging $(60.54 \mathrm{~N}$ vs. $45.63 \mathrm{~N})$, which demonstrates the deeper impact in this meat trait coming from cold shortening events. The overall mean values in $L T L$ intermediate and fast groups did not significantly differ. However, the progress of the aging proteolytic process between them 
seems to be distinct, with the intermediate group tending to reach a better quality level early post-mortem (55.87 $\mathrm{N}$ vs. $65.31 \mathrm{~N}$ at day 2), while the fast group extends the tenderization process, reaching even a lower mean shear force value after 28 days of aging (Table 5). Such different behaviors were also reported by other authors, who underlined that they were possibly due to distinct $\mathrm{pH}$ sensitivity patterns of aging enzymes in muscles with distinct anatomical locations, thus promoting the inhibition or activation of caspases and calpains (Kim, Lonergan \& Huff-Lonergan, 2010; Kim, Stuart, Nygaard \& Rosenvold, 2012), enzymes involved in the cleavage of cellular structures early post-mortem (Herrera-Mendez et al., 2006, referring Fischer et al., 2003).

Despite the greater effective probability of heat shortening development in $\mathrm{Gm}$ muscles within $\mathrm{pH}_{2}<6.0$ group, the resulting overall mean shear force value $(56.98 \mathrm{~N})$ did not significantly differ from the other groups with intermediate $(54.45 \mathrm{~N})$ and slow $(48.38 \mathrm{~N})$ rates of $\mathrm{pH}_{2}$ fall. The lower effect related to heat shortening on sarcomere contraction rate at rigor on set and consequently on meat tenderness, may explain the lower differences among $G m$ samples. Nevertheless, the shear force value obtained at day 2 was considerably higher in $\mathrm{pH}<6.0(68.19 \mathrm{~N})$ than in the other groups $(60.7 \mathrm{~N}$ and $61.15 \mathrm{~N}$ in intermediate and slow groups, respectively). Also the difficulty, frequently mentioned (Devine et al., 1999; Dransfield et al., 1992) in heat shortened samples to pursuit post-mortem tenderization only appeared slightly attenuated in $G m$ samples grouped in fast and intermediate rates of $\mathrm{pH}_{2}$ decline ( $28 \%$ and $23 \%$ reduction in shear force from day 2 up to day 28) in relation to that within the slow group ( $35 \%$ reduction). The reported most tender beef obtained when the temperature/pH 6.0 is around $29-30^{\circ} \mathrm{C}$ (Hwang \& Tompson, 2001) was not totally confirmed in our study for the $G m$ muscle.

\subsection{Early Post-Mortem Muscle pH Condition and Meat Moisture Weight Losses}

Least square mean purge, thawing and grilling losses of $G m$ and $L T L$ muscles, as affected by aging time, and muscle rate of $\mathrm{pH}_{2}$ decline are shown in Tables 4 and 5. The aging time, as expected, affected very significantly purge losses in both muscles (Tables 4 and 5). Differently, the significant effect from the rate of $\mathrm{pH}_{2}$ fall was only for purge losses recorded after aging, in both muscles, but to a lower extent in $L T L(P=0.04)$ than in $G m$ muscle $(P<0.001)$.

Regarding the earliest post-mortem stage evaluated in the current study, corresponding to the samples kept in carcasses for 2 days and immediately frozen at $-30^{\circ} \mathrm{C}$ after excision and preparation for analysis (held thereafter at $-18^{\circ} \mathrm{C} /-20^{\circ} \mathrm{C}$ ), the least thawing loss situation was found in the fast rate of $\mathrm{pH}_{2}$ fall in both muscles, reaching $6.63 \%$ and $6.26 \%$ in $G m$ and $L T L$ muscles, respectively (Tables 4 and 5). Regarding the other $\mathrm{pH}_{2}$ groups, the respective weight losses appeared quite leveled between them in both muscles as well, but with that formed in $G m$ at a higher level $(8.11 \%$ - slow vs. $8.74 \%$ - intermediate) than in LTL (6.85\% - slow vs. $6.95 \%$ intermediate). Such quantitative early post-mortem discrimination among the $\mathrm{pH}_{2}$ fall rates assayed, once discounted the increased thawing loss level added by the blast air freezing to the samples (Moore \& Young, 1991; Sacks, Casey, Boshof \& van Zyl, 1993), lack a coherent explanation in view of the results expressed in Figure 1, namely for the $G m$ muscle (best response while submitted to highly probable heat shortening effect).

However, such trend was not confirmed when samples aged under vacuum packaging at $0{ }^{\circ} \mathrm{C}-2{ }^{\circ} \mathrm{C}$ were analyzed. Under these processing conditions, the worse purge formation in $L T L$ muscle appeared associated to the slow group, with an overall mean value significantly higher than the fast group ( $7.78 \%$ vs. $5.76 \%)$ but not differing from that achieved in the intermediate group (5.94\%). If the purging behavior in the slow group may be explained by the higher probability of cold shortening occurrence (Figure 1), the higher overall mean purge level from the intermediate in relation to the fast group $(P>0.05)$ is, apparently, questionable, because these last samples will necessarily reach similar $\mathrm{pH}$ values at higher muscle temperatures $\left(30.25^{\circ} \mathrm{C}\right.$ vs. $\left.17.95^{\circ} \mathrm{C}\right)$. These conditions would increase the associated protein denaturation and implicate a reduction in the respective water holding capacity. However, the higher muscle temperature/ $\mathrm{pH}_{6}$ could also speed up the aging enzymes activity and thus the subsequent hydrolysis of the costameres structure, preventing the myofibrils lateral shrinkage accomplishment and promoting a lower purging intensity (Wang \& Ramirez-Mitchell, 1983; Kristensen \& Purslow, 2001; Melody et al., 2004). Yet, the marginal incidence of cold shortened samples within the intermediate group, as well as their faster $\mathrm{pH}$ decline rate between the $2^{\text {nd }}$ and the $6^{\text {th }}$ hour post-mortem, referred before, could also be responsible for those different values. Concerning the $\mathrm{Gm}$ muscle, the worse purge quality status came from the intermediate $\mathrm{pH}_{2}$ fall rate $(8.19 \%$ - overall mean value) significantly higher than the level achieved from the slow group (5.95\%) but not differing from that obtained within the faster group $(7.20 \%)$. Here again, the relative purge overall mean discrimination between fast and intermediate groups seems to be somewhat distorted, attending to their temperature at $\mathrm{pH} 6.0$ crossing point within the ideal window of quality, showed in Figure 1. Apparently, under the Gm physico-chemical post-mortem environment, the balance resulting from the factors affecting the water holding capacity is slightly more negative in the intermediate than in the fast group (Kim et al., 2012). Hopkins et al., (2014) also reported no significant differences in the eating quality of 
two beef cuts obtained from stimulated and non stimulated carcasses aged for 1 and 14 days, which had temperature $/ \mathrm{pH} 6.0$ mean values of $40.9^{\circ} \mathrm{C}$ and $33.3^{\circ} \mathrm{C}$, respectively. The main reason referred by the authors for this result was the fact that the model used to define the beef quality standards did not include the $\mathrm{pH}$ decline rate as a predictive trait.

Table 4. Purge, thawing and grilling losses and Warner-Bratzler shear force (WBsf) least square means of samples from $\mathrm{Gm}$ muscle of cull dairy cows in relation to the rate of $\mathrm{pH}_{2}$ fall and aging time

\begin{tabular}{|c|c|c|c|c|c|c|c|c|}
\hline & & \multicolumn{3}{|c|}{$\mathrm{pH}$ fall groups } & \multirow[b]{2}{*}{ SE } & & & \\
\hline & & $\mathrm{pH}_{2}<6.0$ & $6.0<\mathrm{pH}_{2}<6.4$ & $\mathrm{pH}_{2}>6.4$ & & \multicolumn{3}{|c|}{$P$ value } \\
\hline & & $\mathrm{n}=14$ & $\mathrm{n}=11$ & $\mathrm{n}=7$ & & $\begin{array}{c}\text { Rate } \mathrm{pH} \\
\text { fall }(\mathrm{RpH})\end{array}$ & $\begin{array}{l}\text { Aging time } \\
\text { (At) }\end{array}$ & $\mathrm{RpH}^{*} \mathrm{At}$ \\
\hline & 7 & 4.13 & 4.70 & 2.75 & & & & \\
\hline Purge losses & 14 & 5.98 & 7.27 & 4.97 & & & & \\
\hline \multirow[t]{2}{*}{$(\%)$} & 28 & 8.95 & 9.88 & 7.79 & 0.50 & $<0.001$ & $<0.001$ & 0.968 \\
\hline & 42 & 9.74 & 10.90 & 8.31 & & & & \\
\hline \multicolumn{2}{|c|}{ Overall mean } & $7.20^{a b}$ & $8.19^{a}$ & $5.95^{b}$ & & & & \\
\hline \multirow{5}{*}{$\begin{array}{c}\text { Thawing losses } \\
(\%)\end{array}$} & 2 & 6.63 & 8.74 & 8.11 & & & & \\
\hline & 7 & 5.92 & 7.49 & 4.70 & & & & \\
\hline & 14 & 4.88 & 5.25 & 4.66 & 0.82 & 0.123 & $<0.001$ & 0.537 \\
\hline & 28 & 4.55 & 5.42 & 4.07 & & & & \\
\hline & 42 & 4.63 & 4.76 & 4.43 & & & & \\
\hline \multicolumn{2}{|c|}{ Overall mean } & 5.32 & 6.34 & 5.19 & & & & \\
\hline \multirow{5}{*}{$\begin{array}{c}\text { Grilling losses } \\
\text { (\%) }\end{array}$} & 2 & 25.84 & 21.08 & 24.18 & & & & \\
\hline & 7 & 25.67 & 23.91 & 25.54 & & & & \\
\hline & 14 & 23.95 & 24.13 & 25.12 & 1.04 & 0.123 & 0.013 & 0.05 \\
\hline & 28 & 24.64 & 25.35 & 24.96 & & & & \\
\hline & 42 & 25.87 & 25.35 & 27.56 & & & & \\
\hline \multicolumn{2}{|c|}{ Overall mean } & 25.19 & 23.96 & 25.47 & & & & \\
\hline \multirow{4}{*}{$\begin{array}{c}\text { Total losses } \\
(\%)\end{array}$} & 7 & 35.54 & 36.11 & 33.76 & & & & \\
\hline & 14 & 35.15 & 36.70 & 34.90 & & & & \\
\hline & 28 & 37.89 & 40.52 & 37.58 & 1.40 & 0.509 & $<0.001$ & 0.503 \\
\hline & 42 & 39.99 & 41.11 & 40.50 & & & & \\
\hline \multicolumn{2}{|c|}{ Overall mean } & 36.26 & 36.94 & 35.59 & & & & \\
\hline \multirow{4}{*}{$\begin{array}{l}\text { WBsf } \\
(\mathrm{N})\end{array}$} & 2 & 68.19 & 60.70 & 61.15 & & & & \\
\hline & 7 & 56.22 & 57.21 & 52.73 & & & & \\
\hline & 14 & 54.21 & 53.35 & 40.18 & 6.11 & 0.564 & $<0.001$ & 0.885 \\
\hline & 28 & 49.31 & 46.52 & 39.44 & & & & \\
\hline \multicolumn{2}{|c|}{ Overall mean } & 56.98 & 54.45 & 48.38 & & & & \\
\hline
\end{tabular}

Overall means with different superscript letters are significantly different, $P<0.05$ (Tukey HSD post hoc test). $\mathrm{SE}$ - Standard error. 
Table 5. Purge, thawing and grilling losses and Warner-Bratzler shear force (WBsf) least square means of samples from $L T L$ muscle of cull dairy cows in relation to the rate of $\mathrm{pH}_{2}$ fall and aging time

\begin{tabular}{|c|c|c|c|c|c|c|c|c|}
\hline & & \multicolumn{3}{|c|}{$\mathrm{pH}$ fall groups } & \multirow[b]{2}{*}{ SE } & & & \\
\hline & & $\mathrm{pH}_{2}<6.0$ & $6.0<\mathrm{pH}_{2}<6.4$ & $\mathrm{pH}_{2}>6.4$ & & \multicolumn{3}{|c|}{$P$ value } \\
\hline & & $\mathrm{n}=16$ & $\mathrm{n}=12$ & $\mathrm{n}=4$ & & $\begin{array}{c}\text { Rate } \mathrm{pH} \\
\text { fall }(\mathrm{RpH})\end{array}$ & $\begin{array}{l}\text { Aging time } \\
\text { (At) }\end{array}$ & $\mathrm{RpH}^{*} \mathrm{At}$ \\
\hline & 7 & 2.99 & 2.66 & 4.89 & & & & \\
\hline Purge losses & 14 & 5.03 & 4.90 & 7.53 & & & & \\
\hline \multirow[t]{2}{*}{$(\%)$} & 28 & 6.88 & 7.64 & 10.11 & 0.61 & 0.040 & $<0.001$ & 0.162 \\
\hline & 42 & 8.13 & 8.54 & 8.57 & & & & \\
\hline \multicolumn{2}{|c|}{ Overall mean } & $5.76^{b}$ & $5.94^{a b}$ & $7.78^{a}$ & & & & \\
\hline \multirow{5}{*}{$\begin{array}{c}\text { Thawing losses } \\
(\%)\end{array}$} & 2 & 6.26 & 6.95 & 6.85 & & & & \\
\hline & 7 & 4.66 & 6.70 & 3.73 & & & & \\
\hline & 14 & 5.35 & 4.13 & 4.38 & 0.82 & 0.642 & $<0.001$ & 0.156 \\
\hline & 28 & 4.27 & 4.88 & 4.44 & & & & \\
\hline & 42 & 4.07 & 3.93 & 4.13 & & & & \\
\hline \multicolumn{2}{|c|}{ Overall mean } & 4.92 & 5.32 & 4.71 & & & & \\
\hline \multirow{5}{*}{$\begin{array}{c}\text { Grilling losses } \\
(\%)\end{array}$} & 2 & 21.69 & 24.00 & 25.21 & & & & \\
\hline & 7 & 23.03 & 25.29 & 26.35 & & & & \\
\hline & 14 & 22.93 & 27.63 & 26.14 & 1.35 & 0.137 & $<0.001$ & 0.105 \\
\hline & 28 & 25.79 & 25.71 & 30.29 & & & & \\
\hline & 42 & 27.29 & 27.54 & 26.90 & & & & \\
\hline \multicolumn{2}{|c|}{ Overall mean } & 24.15 & 26.03 & 26.98 & & & & \\
\hline \multirow{4}{*}{$\begin{array}{c}\text { Total losses } \\
(\%)\end{array}$} & 7 & 31.22 & 35.22 & 33.25 & & & & \\
\hline & 14 & 34.00 & 37.37 & 35.74 & & & & \\
\hline & 28 & 37.52 & 39.83 & 42.49 & 1.91 & 0.110 & $<0.001$ & 0.041 \\
\hline & 42 & 40.61 & 41.39 & 32.04 & & & & \\
\hline \multicolumn{2}{|c|}{ Overall mean } & 34.31 & 36.95 & 34.76 & & & & \\
\hline \multirow{4}{*}{$\begin{array}{c}\text { WBsf } \\
(\mathrm{N})\end{array}$} & 2 & 65.31 & 55.87 & 82.92 & & & & \\
\hline & 7 & 52.52 & 53.74 & 73.89 & & & & \\
\hline & 14 & 51.35 & 49.87 & 59.11 & 5.25 & 0.038 & $<0.001$ & 0.169 \\
\hline & 28 & 45.63 & 52.26 & 60.54 & & & & \\
\hline \multicolumn{2}{|c|}{ Overall mean } & $53.55^{a b}$ & $53.00^{b}$ & $69.18^{a}$ & & & & \\
\hline
\end{tabular}

Overall means with different superscript letters are significantly different, $\mathrm{P}<0.05$ (Tukey HSD post hoc test).

$\mathrm{SE}-$ Standard error.

Differences between the most and the least purging $\mathrm{pH}_{2}$ groups after aging for 7,14 and 28 days were greater in $G m$ than in $L T L$ muscle (7.11 \% vs $6.49 \%$ ) (Tables 4 and 5). Comparing $L T L$ samples with $\mathrm{pH}_{2}>6.4$ and $\mathrm{pH}_{2}<$ 6.0 , the former condition showed $38.9 \%, 33.2 \%$ and $32.0 \%$ higher mean purge levels after 7, 14 and 28 days of aging, respectively. These gaps in $\mathrm{Gm}$ muscles were considerably lower, namely those found for the longer aging periods ( $+33.4 \%$ - 7 days; $16.9 \%$ - 14 days and $12.9 \%$ - 28 days). Such apparent lower relative impact in purge formation of samples passing by a heat-shortening situation is an unexpected result. Under this condition, the amount of free water in and out of the myofibrillar compartments is referred to increase considerably, due to the protein denaturation and the concomitant decrease in the sarcomere length at rigor, which should facilitate its flow into the extracellular space (Guinot, Vignon, \& Monin, 1993). Regarding the different groups of $\mathrm{pH}_{2}$ fall rates aged for 42 days, the differences in purge formation appeared much more attenuated in LTL $(5.1 \%)$ 
comparatively to $G m$ muscle (14.6\%). The slow decrease in purging after 42 days of aging or even its lower mean level in relation to that found after 28 days aging period (LTL slow group), could be due to some reabsorption by the muscle protein network or to the sponge effect suggested by Farouk, Mustafa, Wu, \& Krsinic (2012). Irrespective of muscle $\mathrm{pH}_{2}$ fall rate, purging production decreased with the aging time in both muscles. This corroborates the findings of Farouk et al. (2012), who stressed that, apart from the increasing values of drip after the first week of aging, the water holding capacity of beef improves thereafter, whatever the temperature that rigor sets in. Other studies also confirm this behavior in different meat animal species (Farouk et al., 2007; Farouk, Wiklund, Stuart \& Dobbie, 2009; Zhang, Lonergan, Gardner, \& Huff-Lonergan, 2006).

The thawing losses decreased with the meat aging time. According to Bertram et al. (2002), moisture weight losses from meat develop as an ongoing process, involving the water transfer from the myofibrils microstructure to the extra myofibrillar and then to the extracellular space. Thawing weight loss from $G m$ was, in average, higher than that of $L T L$ muscle (Tables 4 and 5) for samples having similar temperature/pH 6.0 values (eg. Gm intermediate group vs. $L T L$ fast group).

Under the heat pressure of grilling treatment, the distinct rates of $\mathrm{pH}_{2}$ fall did not produce significantly different losses in both muscles. The effect attributed to the aging time ( $P=0.0009$ and $P=0.013$ for $L T L$ and $G m$ muscles, respectively) reflected a somewhat erratic behavior within each $\mathrm{pH}_{2}$ group. Nevertheless, a trend for slightly higher purge values in samples aged for longer periods was verified for both muscles, which is opposite to that reported in Devine et al. (2002) and Wheeler, Savell, Cross, Lunt \& Smith (1990) for cooking processed samples. Under grilling, our results mostly seem to express differences in sample geometry (shape/dimension) and volume relationship, which may provide distinct heating intensities, affecting conjunctive tissue structure and determining weight losses. At grilling the results varied between a minimum of $22 \%$ in both muscles and a maximum of about $27 \%$ in $L T L$ and $29 \%$ in $\mathrm{Gm}$. If samples aged for different periods were pooled together, then the average losses under grilling within the different $\mathrm{pH}_{2}$ groups were very close in both muscles (less than $1 \%$ ).

Based on total purge losses obtained from both muscles, no coherent relationship among distinct $\mathrm{pH}_{2}$ conditions and samples aging periods assayed can be formulated. Overall, the difference among mean values reached around $1 \%$ in $L T L$ and less than $3 \%$ in $G m$. In the former muscle, samples with $\mathrm{pH}_{2}>6.4$ presented the lower level whereas in $G m$ this performance was related to the faster condition (Tables 4 and 5).

\section{Conclusions}

The post-mortem rate of $\mathrm{pH}$ decline significantly affected purging and tenderness of meat from culled dairy cows after aging. Meat from $L T L$ with intermediate and fast $\mathrm{pH}_{2}$ fall rates showed the best tenderness and water holding capacity, respectively, while the slow group presented the poorest quality standard due to its temperature/pH 6.0 relationship compatible with cold shortening development. Differently, the most tender and less purging meat from $\mathrm{Gm}$ muscle was obtained from samples having slow rate of $\mathrm{pH}_{2}$ fall, with the other two $\mathrm{pH}_{2}$ fall groups showing the poorest condition for both traits, due to temperature/pH 6.0 relationship passing the ideal quality interval at the hot end, being more exposed to heat shortening events.

Additional processing treatments before consumption (thawing, grilling) tend to level the existing differences in moisture losses among $\mathrm{pH}_{2}$ groups. In order to optimize culled dairy cows meat quality, their carcasses processing, namely the chilling regime management, has to attend to the large range of variation in animals body condition and to the intrinsic biochemical characteristics of distinct muscles.

\section{References}

Bertram, H. C., Purslow, P. P., \& Andersen, H. J. (2002). Relationship between meat structure, water mobility, and distribution: a low- field nuclear magnetic resonance study. Journal of Agricultural and Food Chemistry, 50, 824-829. http://dx.doi.org/10.1021/jf010738f

Devine, C. E., Wahlgren, N. M., \& Tornberg, E. (1999). Effect of rigor temperature on muscle shortening and tenderisation of restrained and unrestrained beef m. longissimus thoracis et lumborum. Meat Science, 51, 61-72. http://dx.doi/10.1016/S0309-1740(98)00098-9

Devine, C. E., Payne, S. R., Peachey, B. M., Lowe, T. E., Ingram, J. R., \& Cook, C. J. (2002). High and low rigor temperature effects on sheep meat tenderness and ageing. Meat Science, 60, 141-146. http://dx.doi/10.1016/S0309-1740(01)00115-2

Dransfield, E. (1992). Modelling post-mortem tenderization-III: Role of calpain I in conditioning. Meat Science, 31, 85. http://dx.doi/10.1016/0309-1740(92)90074-E

Dransfield, E., Etherington, D. J., \& Taylor, M. A. J. (1992). Modelling post-mortem tenderisation-II: enzyme 
changes during storage of electrically stimulated and non-stimulated beef. Meat Science, 31, $75-84$. http://dx.doi/10.1016/0309-1740(92)90073-D

EC (European Commision). (2006). Commission regulation 103/2006/EC of 20 January 2006 adopting additional provisions for the application of the Community scale for the classification of carcases of adult bovine animals. $\quad$ Retrieved from http:/eur-lex.europa.eu/legal-content/EN/TXT/PDF/?uri=CELEX:32006R0103\&from=EN

Farouk, M. M., Beggan, M., Hurst, S., Stuart, A., Dobbie, P. M., \& Bekhit, A. E. D. (2007). Meat quality attributes of chilled venison and beef. Journal of Food Quality, 30, 1023-1039. http://dx.doi/10.1111/j.1745-4557.2007.00175.x

Farouk, M. M., Wiklund, E., Stuart, A., \& Dobbie, P. (2009). Ageing prior to freezing improves waterholding capacity in beef and venison. The 55th International Congress of Meat Science and Technology (ICoMST), Copenhagen, Denmark, 16-21 August 2009 (pp. 781-785).

Farouk, M. M., Mustafa, N. Md., Wu, G., \& Krsinic, G. (2012). The "sponge effect" hypothesis: An alternative explanation of the improvement in the waterholding capacity of meat with ageing. Meat Science, 90, 670-677. http://dx.doi/10.1016/j.meatsci.2011.10.012

Geesink, G. H., Koolmees, P. A., Van Laack, H. L. J. M., \& Smulders, F. J. M. (1995). Determinants of tenderization in beef Longissimus dorsi and Triceps brachii. Meat Science, 41, 7-17. http://dx.doi/10.1016/0309-1740(94)00066-G

Guinot, F., Vignon, X., \& Monin, G. (1993). Post-mortem evolution of myofilament spacing and extracellular space in veal muscle. Meat Science, 33, 333-347. http://dx.doi/10.1016/0309-1740(93)90005-3

Herrera-Mendez, C.H., Becila, S., Boudjellal, A. \& Ouali, A. (2006). Meat ageing: reconsideration of the current concept. Trends in Food Science and Technology, 17, 394-405. http://dx.doi/10.1016/j.tifs.2006.01.011

Honikel, K. O., Kim, C. J., Hamm, R., \& Roncales, P. (1986). Sarcomere shortening of prerigor muscles and its influence on drip loss. Meat Science, 16, 267-282. http://dx.doi/10.1016/0309-1740(86)90038-0

Hopkins, D. L., Ponnampalam, E. N., van de Ven, R. J., \& Warner, R. D. (2014). The effect of pH decline rate on the meat and eating quality of beef carcasses. Animal Production Science, 54, 407-413. http://dx.doi.org/10.1071/AN12314

Hwang, I. H., \& Thompson, J. M. (2001). The interaction between pH and temperature decline early postmortem on the calpain system and objective tenderness in electrically stimulated beef longissimus dorsi muscle. Meat Science, 58, 167-174. http://dx.doi.org/10.1016/S0309-1740(00)00147-9

JMP. (2010). The statistical software. Cary, NC: SAS Institute, Inc.

Judge, M. D., Reeves, E. S., \& Aberle, E. D. (1981). Effect of electrical stimulation on thermal shrink- age temperature of bovine muscle. Journal of Animal Science, 52, 530.

Kauffman, R. G., \& Marsh, B. B. (1987). Quality characteristics of muscle as food. In (J. F. Price and B. S. Schweigert (Eds.), The Science of Meat and Meat Products (pp. 349-369, 155). Food \& Nutrition Press, Inc., Westport, CT, USA.

Kim, Y. H., Lonergan, S. M., \& Huff-Lonergan, E. (2010). Protein denaturing conditions in beef deep semimembranosus muscle results in limited $\mu$-calpain activation and protein degradation. Meat Science, 86, 883-887. http://dx.doi.org/10.1016/j.meatsci.2010.06.002

Kim, Y. H. B., Stuart, A., Nygaard, G., \& Rosenvold, K. (2012). High pre rigor temperature limits the ageing potential of beef that is not completely overcome by electrical stimulation and muscle restraining. Meat Science, 91, 62-68. http://dx.doi.org/10.1016/j.meatsci.2011.12.007

Kristensen, L., \& Purslow, P. P. (2001). The effect of ageing on the water-holding capacity of pork: role of cytoskeletal proteins. Meat Science, 58, 17-23. http://dx.doi.org/10.1016/S0309-1740(00)00125-X

Locker, R.H. \& Hagyard, C. J. (1963). A cold shortening effect in beef muscles. Journal of the Science of Food and Agriculture, 14, 787-793. http://dx.doi.org/10.1002/jsfa.2740141103

Lonergan, E. H., \& Lonergan, S. M. (2005). Mechanisms of water-holding capacity of meat: The role of postmortem biochemical and structural changes. Meat Science, 71, $194-204$. http://dx.doi.org/10.1016/j.meatsci.2005.04.022

Marsh, B. B. (1993). Approaches to manipulate postmortem metabolism and meat quality. In Proceedings of the 
39th International Congress of Meat Science and Technology, Calgarly, Canada (pp. 111-123).

Marsh, B. B., Ringkob, T. P., Russell, R. L., Swartz, D. R., \& Pagel, L. A. (1987). Effects of early-postmortem glycolytic rate on beef tenderness. Meat Science, 21, 241-248. http://dx.doi.org/10.1016/0309-1740(87)90061-1

Melody, J. L., Lonergan, S. M., Rowe, L. J., Huiatt, T. W., Mayes, M. S., \& Huff-Lonergan, E. (2004). Early postmortem biochemical factors influence tenderness and water-holding capacity of three porcine muscles. Journal of Animal Science, 82, 1195-1205.

Miller, M. F., Carr, M. A., Ramsey, C. B., Crockett, K. L., \& Hoover, L. C. (2001). Consumer thresholds for establishing the value of beef tenderness. Journal of Animal Science, 79, 3062-3068. http://dx.doi.org/2001.79123062x

Moore, V. J., \& Young, O. A. (1991). The effects of electrical stimulation, thawing, ageing and packaging on the colour and display life of lamb shops. Meat Science, 30, 131-145. http://dx.doi.org/10.1016/0309-1740(91)90003-9

Offer, G. (1991). Modeling of the formation of pale, soft and exudative meat - effects of chilling regime and rate and extent of glycolysis. Meat - effects of chilling regime and rate and extent of glycolysis. Meat Science, 30, 157-184. http://dx.doi.org/10.1016/0309-1740(91)90005-B

Offer, G., \& Trinick, J. (1983). On the mechanism of water holding in meat: the swelling and shrinking of myofibrils. Meat Science, 8, 245-281. http://dx.doi.org/10.1016/0309-1740(83)90013-X.

Offer, G., \& Knight, P. (1988). The structural basis of water-holding capacity in meat. Part 2: drip losses. In R. Lawrie (Ed.). Developments in meat science (Vol. 4, pp. 173-243). London: Elsevier Science Publications.

Ouali, A., Herrera-Mendez, C. H., Coulis, G., Becila, S., Boudjellal, A., Aubry, L., \& Sentandreu, M. A. (2006). Revisiting the conversion of muscle into meat and the underlying mechanisms. Meat Science, 74, 44-58. http://dx.doi.org/10.1016/j.meatsci.2006.05.010

Rees, M. P., Trout, G. R., \& Warner, R. D. (2003). The influence of rate of $\mathrm{pH}$ decline in the rate of ageing for pork. II Interaction with chilling temperature. Meat Science, 65, 805-818. http://dx.doi.org/10.1016/S0309-1740(02)00285-1

Roseiro, L. C., Santos, C., \& Melo, R. S. (1994). Muscle $\mathrm{pH}_{60}$, Color (L; a; b) and Water Holding Capacity and the Influence of Post-mortem Meat Temperature. Meat Science, 38, 353-359. http://dx.doi.org/10.1016/0309-1740(94)90124-4

Roseiro, L. C., Santos, C., Gonçalves, H., Moniz, C., Afonso, I., Tavares, M., \& da Ponte, D. J. B. (2014). Concentration of antioxidants in two muscles of mature dairy cows from Azores. Meat Science, 96, 870-875. http://dx.doi.org/10.1016/j.meatsci.2013.09.005.

Sacks, B., Casey, N. H., Boshof, E., \& van Zyl, H. (1993). Influence of freezing method on thaw drip and protein loss of low-voltage electrically stimulated and non-stimulated sheep's muscle. Meat Science, 34, 235-243. http://dx.doi.org/10.1016/0309-1740(93)90030-L

Salm, C. P., Forrest, J. C., Aberle, E. D., Mills, E. W., Snyder, A. C., \& Judge, M. D. (1983). Bovine muscle shortening and protein degradation after electrical stimulation, excision and chilling. Meat Science, 8, 163-183. http://dx.doi.org/10.1016/0309-1740(83)90043-8

Schafer, A., Rosenvold, K., Purslow, P. P., Andersen, H. J., \& Henckel, P. (2002). Physiological and structural events postmortem of importance for drip loss in pork. Meat Science, 61, 355-366. http://dx.doi.org/10.1016/S0309-1740(01)00205-4

Sentandreu, M. A., Coulis, G., \& Ouali, A. (2002). Role of muscle endopeptidases and their inhibitors in meat tenderness. Trends Food Sciences and Technology, 13, 400-421. http://dx.doi.org/10.1016/S0924-2244(02)00188-7

Tornberg E. (1996). Biophysical aspects of meat tenderness. Meat Science, 43, S175-S191. http://dx.doi.org/10.1016/0309-1740(96)00064-2

Wang, K., \& Ramirez-Mitchell, R. (1983). A network of transverse and longitudinal intermediate filaments is associated with sarcomeres of adult vertebrate skeletal-muscle. Journal of Cell Biology, 96, 562-570. http://europepmc.org/backend/ptpmcrender.fcgi?accid=PMC2112278\&blobtype=pdf 
Wheeler, T. L., Savell, J. W., Cross, H. R., Lunt, D. K., \& Smith, S. B. (1990). Effect of post-mortem treatments on the tenderness of meat from Hereford, Brahman and Brahman-cross beef cattle. Journal of Animal Science, 68, 3677-3686. http://www.researchgate.net/publication/20894492

Zhang, W. G., Lonergan, S. M., Gardner, M. A., \& Huff-Lonergan, E. (2006). Contribution of postmortem changes of integrin, desmin and $\boldsymbol{\mu}$-calpain to variation in water holding capacity of pork. Meat Science, 74, 578-585. http://dx.doi.org/10.1016/j.meatsci.2006.05.008

\section{Copyrights}

Copyright for this article is retained by the author(s), with first publication rights granted to the journal.

This is an open-access article distributed under the terms and conditions of the Creative Commons Attribution license (http://creativecommons.org/licenses/by/3.0/). 